\title{
An integrative review of studies of condom use among Korean college students
}

\author{
Yoonjung Kim ${ }^{1}$, Hye Young Min ${ }^{1}$, Jungmin Lee ${ }^{2}$, Shin-Jeong Kim ${ }^{3}$ \\ ${ }^{1}$ Doctoral Candidate, College of Nursing, Ewha Womans University, Seoul; ${ }^{2}$ Lecturer, School of Nursing, Hallym University, Chuncheon; ${ }^{3}$ Professor, School of \\ Nursing, Research Institute of Nursing Science, Hallym University, Chuncheon, Korea
}

Purpose: The purpose of this study was (a) to synthesize studies of condom use among South Korean college students, and (b) to appraise the quality of each article using Gough's weight of evidence. Methods: Studies published in English and Korean were searched in electronic databases using the terms "student or college student or university student or undergraduate", "condom", and "Korea*". Results: Twenty studies met the inclusion criteria, showed appropriate quality, and were therefore selected for review. The variables related to condom use were measured in terms of condom-related factors, factors related to non-condom-related knowledge and attitudes, and other factors. Knowledge, attitudes, and self-efficacy were associated with condom use, and there were differences in condom-related factors among men and women. Conclusion: Based on these findings, it was confirmed that sexual education is needed for both men and women to promote condom use. Education on condom use should not only focus directly on condoms, but should also address other aspects of knowledge and attitudes to influence health beliefs. In addition, developing educational programs targeting adolescents and parents will have a positive effect on college students' condom use.

Key words: Condom; Health education; Review; Students

\section{Corresponding author Jungmin Lee \\ https://orcid.org/0000-0002-4916-5485}

School of Nursing, Hallym University,

1 Hallymdaehak-gil, Chuncheon 24252, Korea

TEL +82-31-398-7821 FAX +82-31-398-7821

E-MAIL sae7821@gmail.com

Received Dec 14, 2020 Revised Dec 27, 2020 Accepted Dec 29, 2020 (a) This is an Open Access article distributed under the terms of the Creative Commons Attribution NonCommercial License (http://creativecommons.org/licenses/by-nc/4.0/) which permits unrestricted noncommercial use, distribution, and reproduction in any medium, provided the original work is properly cited.

\section{INTRODUCTION}

Early adulthood is a time of transition from adolescence to adulthood when sufficient physical maturity is reached to engage in sexual relationships or activities [1]. This is also a time when people become more sexually active and experience the strongest sexual desires. As young adults may be highly emotional and have opportunities to make dangerous sexual choices in situations where they face strong temptations, young people may experience more difficulties in controlling their sexual curiosity and desires than those in other age groups [2]. Furthermore, young people who are not ready for safe sexual relationships are considered to be a high-risk group for sexually transmitted infections (STIs), including human immunodeficiency virus (HIV), as the number of college students who have had sexual intercourse is increasing, the age at first sexual intercourse is decreasing [3], and college students can participate in various dangerous sexual activities [4]. According to the results of one study, people under the age of 25 years are at a higher risk of exposure to STIs because they have more frequent changes in partners than do people in other age groups [5].

The incidence of STIs is increasing worldwide, especially among those in their 20s [6]. According to a study by Subbarao and Aknilesh [4], young people aged between 16 and 24 are at 
a higher risk of STIs than adults. As STIs can affect future sexual activities, they have particularly severe consequences for young people [7]. If an STI is left untreated, it can last for the rest of one's life, leading to serious long-term health problems [8]. Despite these negative effects, STIs have steadily become more common among young people in Korea [9]. The number of people diagnosed with STIs increased by 1.24 times over the past 5 years, with a 2.5-fold increase in those aged 20 to 30 years from 3,000 in 2012 to 7,600 in 2016 [10]. Additionally, according to Park et al. [11], 64.1\% of young people under probation in Korea have engaged in sexual intercourse; of these, $56.1 \%$ had at least one type of STI. Therefore, there is a need for appropriate measures and actions related to this matter among young people. Moreover, the South Korea Disease Control Headquarters [12] stated that, in 2017, individuals in their 20s accounted for the highest proportion of newly diagnosed HIV cases. In South Korea from 2015 to 2017, the most common route of HIV infection among young people was unprotected sex $[12,13]$.

There are various methods to avoid contracting STIs, such as not having sex with strangers, postponing sexual intercourse until one is older, and using condoms during sex [14]. One of the most effective methods of preventing STIs is to encourage the use of condoms for safe sex [15]. To prevent STIs, the Centers for Disease Control and Prevention (CDC) [14] suggest avoiding dangerous sexual activities and always using condoms during vaginal, anal, and oral sex. Encouraging the regular use of condoms is a common method to reduce the dangers of sexual intercourse among young people, and is considered to be an important, cost-effective, and accessible method to prevent STIs [16,17]. However, the use of condoms and birth control use by college students is extremely low worldwide [18].

Despite the openness of Korean sex culture, it has not embraced the need to purchase condoms. The low rate of contraception use among South Korean college students results in an increased risk of exposure to negative sexual health problems [19], including STIs, unwanted pregnancies, and abortions, and it is therefore imperative that more efforts should be made to facilitate a healthy sex life among young people in South Korea. According to a study conducted by Lee [20], only $25.0 \%-38.2 \%$ of young Korean people used condoms appropriately, resulting in $17.1 \%$ of young Koreans having STIs [11]. Due to the low use of condoms, there has been an increase in the number of undesired pregnancies, unmarried mothers, abortions, and incidence of STIs [14]. Despite the seriousness of sexual health and the importance of condom use by college students, limited efforts have been made to comprehensively analyze and evaluate these factors. To develop appropriate sexual education programs for Korean college students, it is important to identify predictive factors related to the use of condoms by collecting information on risky sexual activities among college students. Therefore, this study analyzed and evaluated studies concerning the use of condoms by Korean college students. The findings of this study may provide a foundation for research strategies and possible future interventions related to health education to promote safe and healthy sex lives.

\section{METHODS}

\section{Study Design}

This study is an integrative review of research articles on Korean college students' condom use published in Korean and international journals.

\section{Research}

Procedure In this study, the five steps of 1) clarification of the research problem, 2) literature search and selection, 3) data evaluation, 4) data analysis and interpretation of the meaning, and 5) derivation of attributes through data integration were carried out in accordance with the guidelines of Whittemore and Knafl [21]. In addition, the weight of evidence (WOE) methodology of Gough [22] was used to assess the quality of each article by clarifying the research problem.

\section{1) Clarification of the research problem}

The first step in the integrated review process of Whittemore and Knafl [21] is to clarify the research purpose of the respective study. In this study, we formulated the research question as, "What are the characteristics of studies related to condom use among Korean college students?".

\section{2) Literature search and selection}

The second stage is the literature search process, which involves processes to enhance the reliability of the study and the accuracy of the literature search [21]. The following final analysis criteria were modified and supplemented by discussions among the three researchers. The inclusion criteria for the literature review were 1) peer-reviewed papers published in international journals or Korean journals, 2) topics related to the use of condoms among Korean college students, 3) articles including the keyword "condom", and 4) texts published in English or Korean. Studies were excluded if they were master's theses or doctoral dissertations, letters to the editor, or academic conference papers. In addition, articles focusing on other contraceptive methods or general contraceptive methods were also excluded. The literature search and analysis 
was conducted from April to August 2019. Articles published between 2005 and April 2019 were targeted, and we searched for Korean and international studies conducted among Korean college students. To search for articles published in Korean journals, the Academic Research Information Service, National Institute of Science and Technology, Korean Studies Information Service System, National Assembly Library, and Korean Medical Database were used. The keywords used in the search included "students or college student or university student or undergraduate", "condom", and "Korea*". For international publications, four search databases were used (PubMed, CINAHL, PsycINFO, and SCOPUS), and the keywords were combinations of "student or college student or university student or undergraduate", "condom", and "Korea*". In addition, searches were conducted in PubMed for "student or college student or university student or undergraduate", "condom", and "Korea or Korean". Seventy-four articles were retrieved from international databases in the initial search results and 69 from the Korean databases $(N=143)$. Excluding the dupli- cated articles $(n=25)$, a total of 93 articles were excluded after reviewing the title and abstract of each article. Regarding other literature search strategies mentioned by Whittemore and Knafl [19], there were no articles found by either ancestry searching (looking at source lists or relevant articles) or journal hand searching (looking at the tables of contents of journals identified as useful/prolific for the topic). Furthermore, since we limited the literature search to peer-reviewed papers published in international Korean journals, networking and searching research registries were not conducted. Articles that did not match the inclusion criteria of this study were also excluded $(n=5)$ after independent reviews of the abstract and manuscript. As a result, 20 articles were finally included in the analysis. Furthermore, a Preferred Reporting Items for Systematic Reviews and Meta-Analyses flowchart was used during the literature search process of this study (Figure 1).

\section{3) Data evaluation}

It is vitally important to evaluate the quality of the articles

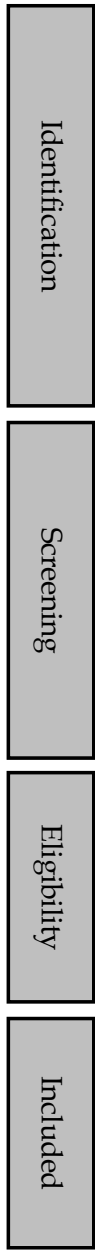

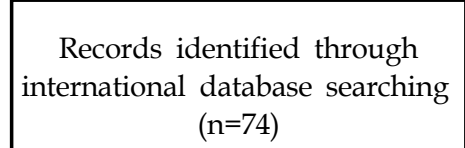
$(\mathrm{n}=74)$
Records identified through

domestic database searching $(n=69)$
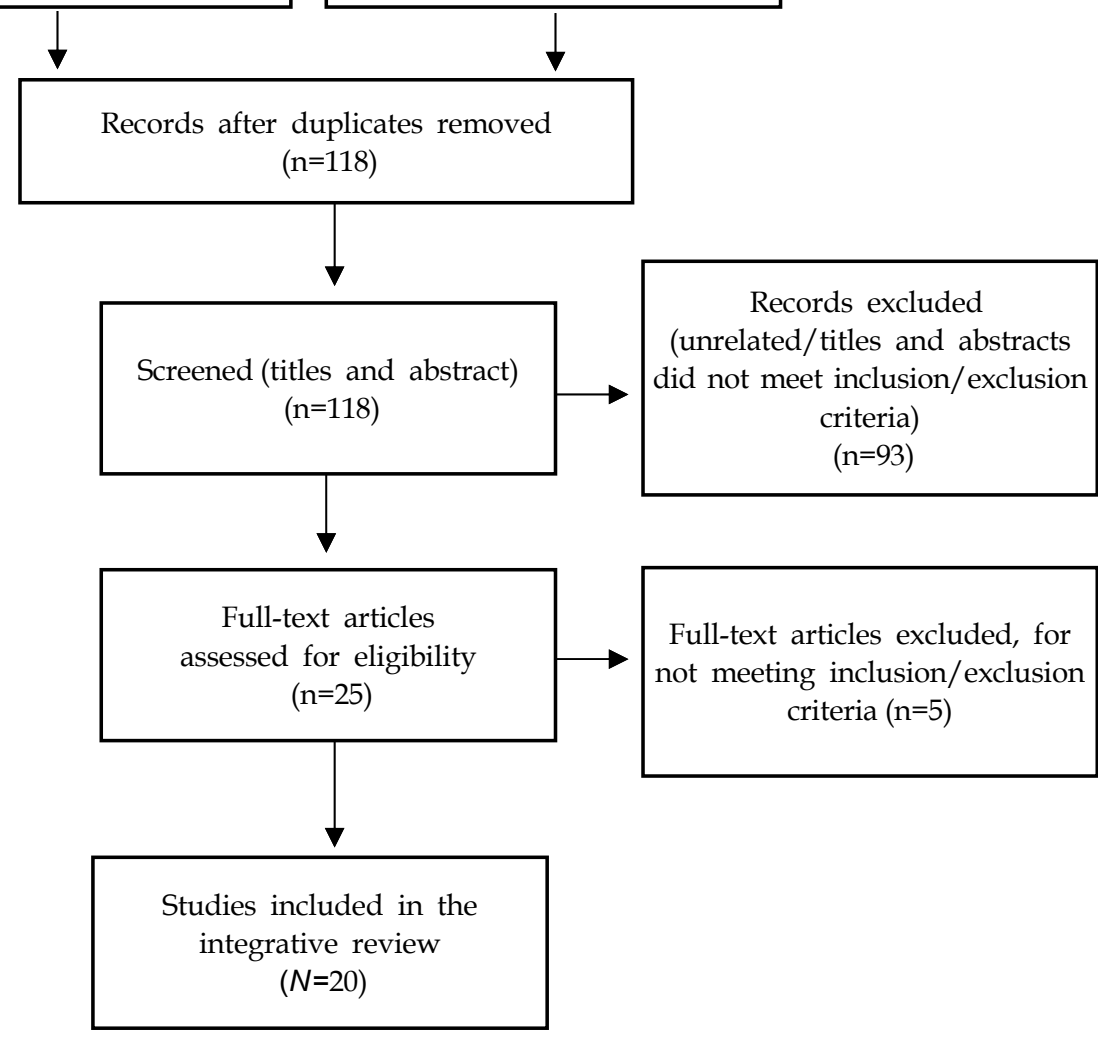

Figure 1. Preferred Reporting Items for Systematic Reviews and Meta-Analyses (PRISMA) flow diagram. 
in an objective manner by strictly applying the relevant criteria [21]. Therefore, we used the analysis frame of Whittemore and Knafl [21] to categorize the findings by author (including the year of publication), research design, independent and dependent variables, outcomes, and implications. In addition, Gough's WOE was used to assess the quality of the study objectives, research design, selection of subjects, and appropriateness of evidence provided to support the research [22]. The WOE is evaluated in four stages to identify the relevance of the proposed research question. There are three analysis criteria with three grades: high, medium, and low. WOE a refers to a comprehensive (and therefore non-review-specific) judgment of the consistency and integrity of the evidence that focuses on the context and evidence of the study as an alternative judgment showing evidence of consistency and integration $[22,23]$. WOE $b$ refers to a review-specific judgment of the adequacy of the respective form of evidence to answer the research question, which entails assessing whether a research design was chosen properly for the research purposes $[22,23]$. WOE c refers to a review-specific judgment of the relevance of the focus of the evidence to the review question, which in turn determines whether the data collection or data analysis was appropriately conducted to address the research question [22,23]. Finally, the WOE, a, b, and c judgments are then combined to form an overall assessment of the extent to which the research contributes evidence to answer the specific research questions (WOE d) [22,23]. According to Gough's study [22], there are no clear criteria on how to calculate the scores. In this regard, we used the score criteria presented in a previous study [24], which provided specific evidence of scoring each criterion based on Gough's assessment. Therefore, among the items evaluated under WOE a, b, and c, the "high" grade is given when two or more items are evaluated as "high", and "medium" when more than two items are classified as "medium".

\section{4) Data analysis and interpretation of the meaning}

Since the authors resided in different countries, all the researchers read and analyzed each article separately, and based on the research problem, the content of each article was summarized and documented through memos for further discussion. For the same reason, we regularly scheduled a meeting of about 2 hours every 2 weeks, and a total of four online video conferences were conducted for more in-depth discussions and to gather opinions. In addition to regular meetings, data analysis was carried out through communication between the researchers using e-mail or telephone.

\section{5) Derivation of attributes through data integration}

According to Whittemore and Knafl [21], the conclusions of the integrated literature review support the conclusions of the study when they appear in the form of tables or figures and show a logical flow, because this can facilitate the comparison and contrast process between studies. Therefore, we created a list of selected research articles and summarized the information and key concepts derived from them (Table 1).

\section{RESULTS}

\section{Characteristics of Studies}

This integrative review analyzed studies related to condom use in Korean college students. The 20 studies on condom use by Korean college students selected for review are listed in Table 1 . The characteristics of the selected studies are presented in Table 2. Fifteen studies (75\%) were published before 2010 and five (25\%) were published in 2010 or after, of which two were published in 2010, one in 2016, and two in 2018. One study was mixed-methods, and the other 19 studies were quantitative. One study had a quasi-experimental design, three had methodology designs, and 14 had cross-sectional correlation designs. Eight of the studies included male students only, one included female students only, and 11 studies included both male and female students. Regarding the number of participants examined, five of the studies had fewer than 300 subjects, seven between 300 and 500, and the others more than 500 .

\section{Results of Data Evaluation}

Two authors conducted a quality evaluation of each article. Eight of the 160 cells showed disagreement and were adjusted after discussion between the researchers (95\% concordance). As a result, the selected papers were judged suitable for review, and all 20 studies were included in the analysis (Table 1). WOE a, an evaluation of the context and basis of the study; WOE $b$, an assessment of suitability for the research purpose; and WOE $d$, a comprehensive judgment measure, were all suitable. Seventeen studies were evaluated as "high" and three as "medium". Among the three studies evaluated as "medium", one study received a medium rating for WOE a, another for WOE c, and the third for WOE $b$ and WOE c.

\section{Analysis of Reviewed Studies}

\section{1) Summaries of studies}

The results of this study are summarized as follows (Table 3). Three studies had the purpose of developing an instrument or confirming the validity of research [A1,A8,A10]. The measurement variables were divided into three categories: con- 
Table 1. Articles Reviewed in this Study $(N=20)$

\begin{tabular}{|c|c|c|c|}
\hline No. & Authors (year) & References & $\begin{array}{l}\text { Gough's WOE } \\
(a-b-c-d)\end{array}$ \\
\hline A1 & $\begin{array}{l}\text { Cha ES, Kim KH, } \\
\text { Burke LE. }\end{array}$ & $\begin{array}{l}\text { Psychometric validation of a condom self-efficacy scale in Korean. Nursing Research. } \\
\text { 2008;57(4):245-251. }\end{array}$ & H-H-H-H \\
\hline $\mathrm{A} 2$ & $\begin{array}{l}\text { Cha ES, Kim KH, } \\
\text { Doswell WM. }\end{array}$ & $\begin{array}{l}\text { Influence of the parent-adolescent relationship on condom use among South Korean } \\
\text { male college students. Nursing and Health Sciences. 2007:9(4):277-283. }\end{array}$ & $\mathrm{H}-\mathrm{H}-\mathrm{M}-\mathrm{H}$ \\
\hline A3 & $\begin{array}{l}\text { Cha ES, Kim KH, } \\
\text { Patrick TE. }\end{array}$ & $\begin{array}{l}\text { Predictors of intention to practice safer sex among Korean college students. Archives of } \\
\text { Sexual Behavior. 2008;37(4):641-651. }\end{array}$ & $\mathrm{H}-\mathrm{H}-\mathrm{H}-\mathrm{H}$ \\
\hline A4 & Cho EJ. & $\begin{array}{l}\text { Effects of sex education on condom attitudes and condom use intention among } \\
\text { undergraduate students - Dramaturgical interaction approach. Journal of Korean } \\
\text { Academy of Community Health Nursing. 2006;17(2):223-234. }\end{array}$ & H-H-H-H \\
\hline A5 & $\begin{array}{l}\text { Cho JY, Ham MY, } \\
\text { Nam BW, Ryu EJ. }\end{array}$ & $\begin{array}{l}\text { Predictors of condom attitude in Korean college students. Journal of the Korean Data } \\
\text { Analysis Society. 2009;11(6):3041-3056. }\end{array}$ & H-H-M-H \\
\hline A6 & Hur TK, Cho JE. & $\begin{array}{l}\text { Condom negotiation strategies of Korean college students: Interactive perspective of } \\
\text { sexual-risk behavior. Korean Psychological Journal of Culture and Social Issues. } \\
\text { 2007;13(1):43-61. }\end{array}$ & H-H-M-H \\
\hline A7 & $\begin{array}{l}\text { Hur TK, Han M, } \\
\text { Kim YS. }\end{array}$ & $\begin{array}{l}\text { Gender differences of risk-taking decisions in sexual behaviors: Condom use and Theory } \\
\text { of Planned Behavior. Korean Journal of Women Psychology. 2004;9(3):69-87. }\end{array}$ & H-H-M-H \\
\hline A8 & Jeong AS, Kim HS. & $\begin{array}{l}\text { Development and validation of benefits, barriers, and self-efficacy measurement tools } \\
\text { for condom use among college students. Journal of the Korean Data Analysis Society. } \\
\text { 2018;20(3):1519-1536. }\end{array}$ & $\mathrm{H}-\mathrm{H}-\mathrm{H}-\mathrm{H}$ \\
\hline A9 & Jun E, Shin HG. & $\begin{array}{l}\text { Factors influencing condom use in male college students. Journal of the Korean Data } \\
\text { Analysis Society. 2016;18(6):3395-3408. }\end{array}$ & H-H-M-H \\
\hline A10 & Kang HS, Chang SB. & $\begin{array}{l}\text { Development of college students' condom attitude scale. Journal of Korean Academy of } \\
\text { Nursing. 2004;34(5):751-759. }\end{array}$ & H-H-M-H \\
\hline A11 & $\begin{array}{l}\text { Kang HS, } \\
\text { Moneyham L. }\end{array}$ & $\begin{array}{l}\text { Use of emergency contraceptive pills and condoms by college students: A survey. } \\
\text { International Journal of Nursing Studies. 2008;45(5):775-783. }\end{array}$ & $\mathrm{H}-\mathrm{H}-\mathrm{M}-\mathrm{H}$ \\
\hline A12 & $\begin{array}{l}\text { Kang HS, } \\
\text { Moneyham, L. }\end{array}$ & $\begin{array}{l}\text { Attitudes toward and intention to receive the human papilloma virus (HPV) vaccination } \\
\text { and intention to use condoms among female Korean college students. Vaccine. } \\
\text { 2010;28(3):811-816. }\end{array}$ & H-H-M-H \\
\hline A13 & Kwon SY, Lee DS. & $\begin{array}{l}\text { Effect of AIDS knowledge, self esteem, sense of control and optimistic bias on condom } \\
\text { use among male college students. Journal of Digital Convergence. 2018;16(1):251-262. }\end{array}$ & $\mathrm{H}-\mathrm{H}-\mathrm{H}-\mathrm{H}$ \\
\hline A14 & $\begin{array}{l}\text { Kwon YM, Yeun EJ, } \\
\text { Kim HY, Youn MS, } \\
\text { Cho JY, Lee HJ. }\end{array}$ & $\begin{array}{l}\text { Application of the transtheoretical model to identify aspects influencing condom use } \\
\text { among Korean college students. Western Journal of Nursing Research. } \\
\text { 2008;30(8):991-1004. }\end{array}$ & H-H-M-H \\
\hline A15 & Lee HK. & $\begin{array}{l}\text { Predictors of condom use intentions according to experience of sexual intercourse in } \\
\text { male college students. Korean Journal of Women Health Nursing. 2010;16(2):194-203. }\end{array}$ & H-H-M-H \\
\hline A16 & Park SH, Han JH. & $\begin{array}{l}\text { Study on the factors influencing the preference to use condoms in male college students. } \\
\text { Journal of Korean Society for Health Statistics. 2000;25(1):59-66. }\end{array}$ & H-H-M-H \\
\hline A17 & Park SH, Lim DO. & $\begin{array}{l}\text { Factors influencing the self-confidence of using condoms in male college students. } \\
\text { Journal of Korean Public Health Association. 2002;28(1):66-71. }\end{array}$ & H-H-M-H \\
\hline A18 & $\begin{array}{l}\text { Park SH, Lim DO, } \\
\text { Han JH. }\end{array}$ & $\begin{array}{l}\text { Factors influencing the attitudes toward condom use in male college students. Journal of } \\
\text { Reproductive Medicine and Population. 2003;16:57-62. }\end{array}$ & H-M-M-M \\
\hline A19 & $\begin{array}{l}\text { Park SH, Lim DO, } \\
\text { Lee BK, Han JH. }\end{array}$ & $\begin{array}{l}\text { Study on the attitudes toward condoms and STIs/AIDS in male college students. Journal } \\
\text { of Reproductive Medicine and Population. 2002;15:46-55. }\end{array}$ & M-M-M-M \\
\hline A20 & Sohn A, Chun SS. & $\begin{array}{l}\text { Gender differences in sexual behavior and condom-related behaviors and attitudes } \\
\text { among Korean youths. Asia-Pacific Journal of Public Health. 2007;19(2):45-52. }\end{array}$ & M-H-M-M \\
\hline
\end{tabular}

H, high; L, low; M, medium; WOE, weight of evidence. 
Table 2. General Characteristics of Reviewed Papers $(N=20)$

\begin{tabular}{|c|c|c|}
\hline Variables & Categories & $\mathrm{n}(\%)$ \\
\hline $\begin{array}{l}\text { Publication } \\
\text { year }\end{array}$ & $\begin{array}{l}<2010 \\
\geq 2010\end{array}$ & $\begin{array}{r}15(75.0) \\
5(25.0)\end{array}$ \\
\hline $\begin{array}{c}\text { Research } \\
\text { design }\end{array}$ & $\begin{array}{l}\text { Quantitative study } \\
\text { Cross-sectional, correlational design } \\
\text { Methodological design } \\
\text { Secondary data analysis } \\
\text { Quasi-experimental design } \\
\text { Mixed-method study }\end{array}$ & $\begin{array}{c}14(70.0) \\
3(15.0) \\
1(5.0) \\
1(5.0) \\
1(5.0)\end{array}$ \\
\hline Participants & $\begin{array}{l}\text { Male } \\
\text { Female } \\
\text { Male and female }\end{array}$ & $\begin{array}{c}8(40.0) \\
1(5.0) \\
11(55.0)\end{array}$ \\
\hline Sample size & $\begin{array}{l}<300 \\
\geq 300 \& \leq 500 \\
>500\end{array}$ & $\begin{array}{l}5(25.0) \\
7(35.0) \\
8(40.0)\end{array}$ \\
\hline $\begin{array}{l}\text { Variables* } \\
\text { Condom-r } \\
\text { Use of } \\
\text { Attituc } \\
\text { Know } \\
\text { Condo } \\
\text { Intenti }\end{array}$ & $\begin{array}{l}\text { lated factors } \\
\text { condoms (consistent and correct use) } \\
\text { e } \\
\text { edge (including benefits of condom use) } \\
\text { m efficacy and self-confidence } \\
\text { on and preference }\end{array}$ & $\begin{array}{r}5(25.0) \\
11(55.0) \\
4(20.0) \\
12(60.0) \\
10(50.0)\end{array}$ \\
\hline $\begin{array}{l}\text { Factors rel } \\
\text { and attitu } \\
\text { Sexual } \\
\text { ECP } \\
\text { STIs/ } \\
\text { HPV v }\end{array}$ & $\begin{array}{l}\text { ited to non-condom-related knowledge } \\
\text { des } \\
\text { behavior } \\
\text { IDS } \\
\text { accine }\end{array}$ & $\begin{array}{r}6(30.0) \\
3(15.0) \\
11(55.0) \\
2(10.0)\end{array}$ \\
\hline $\begin{array}{r}\text { Other fact } \\
\text { Comm } \\
\text { Optim } \\
\text { Subjec }\end{array}$ & $\begin{array}{l}\text { rs } \\
\text { unication } \\
\text { sm bias } \\
\text { ive norms }\end{array}$ & $\begin{array}{l}2(10.0) \\
1(5.0) \\
4(20.0)\end{array}$ \\
\hline
\end{tabular}

*Multiple results; AIDS, acquired immune deficiency syndrome; ECP, emergency contraceptive pills; HPV, human papillomavirus; STI, sexually transmitted infection.

dom-related factors, factors related to non-condom-related knowledge and attitudes (i.e., indirect factors), and other factors such as optimism bias, communication, and subjective norms. Condom-related factors were addressed in five studies of condom use, 11 studies of attitudes, four studies of knowledge, 12 studies of self-efficacy and confidence, and 10 studies of intention and preference for condom use. Knowledge and attitudes also were addressed in six studies on sexual behavior, three on emergency contraceptive pill (ECP) use, 11 on STIs and acquired immune deficiency syndrome (AIDS), and 2 on human papillomavirus (HPV) vaccines.

\section{2) Instruments measuring condom-related variables}

A variety of instruments were used to measure factors related to condoms in the 20 studies (Table 4). Five studies measured the use of a condom; one of these studies used the tool developed by the CDC, while the other four involved questions developed by the researchers. Attitudes about condom use were measured in 11 studies, and the tools included the Condom Attitude Scale (CAS), the College Students' CAS, and the University of California at Los Angeles Multidimensional Condom Attitude Scale. In six other studies, the authors constructed and used their own questions. Condom knowledge was measured in four studies. In one study, knowledge of condoms was measured using an instrument; in another, an instrument measuring the benefits of and barriers to condom use was used, and the authors constructed the questions used in the other two studies. Self-efficacy and confidence towards condom use were measured in 12 studies using three instruments: the Condom Self-efficacy Scale-Korean, Condom Use Self-Efficacy Scale, and Self-efficacy Scale. Ten studies measured intention of use and preference for condoms. The instruments used were the Intention of Sexual Behavior Scale, Intention to Use a Condom Scale, and other questionnaires developed by the authors of each study. Other factors related to knowledge and attitude were sexual behavior, ECP, STIs / AIDS, and HPV vaccines. These factors influenced condom use and shaped how individuals considered potential risk factors. Sexual behavior was investigated in six studies, STIs/AIDS in 12 studies, and ECP and HPV in one study. Sexual behavior included sexual attitudes, autonomy, knowledge, and perceived risk. In studies that investigated STIs/ AIDS, variables regarding knowledge, attitudes, and perceived severity were measured. Lastly, four studies investigated subjective norms, two measured communication patterns with parents, and one measured optimism bias.

\section{3) Outcomes of the studies}

The findings showed that the intention of use was significantly correlated with actual condom use, attitudes towards condoms, and knowledge about condoms. Condom use intention was also found to be influenced by age, and condom use experience, attitudes, and knowledge also showed an indirect effect of communication. Attitudes towards condoms were found to be positively affected by regular use; varied according to age, use, and knowledge; and showed a significant correlation with self-confidence. Condom use was significantly associated with self-control, intention to use, and self-efficacy.

\section{4) The implications of the studies}

In this review, the researchers confirmed gender differences related to condom use. Some studies conducted comparisons by gender. Attitudes, subjective norms, condom efficacy, and intention were found to be significant factors asso- 
Table 3. Summary of Studies Included in the Integrative Review $(N=20)$

\begin{tabular}{|c|c|c|c|c|c|c|c|}
\hline \multirow{2}{*}{$\begin{array}{l}\text { Author } \\
\text { (year) }\end{array}$} & \multicolumn{3}{|c|}{ Design } & \multirow[b]{2}{*}{ Purpose } & \multirow{2}{*}{$\begin{array}{l}\text { Outcome } \\
\text { variables }\end{array}$} & \multirow[b]{2}{*}{ Key findings } & \multirow[b]{2}{*}{ Implications } \\
\hline & $\begin{array}{c}\text { Research } \\
\text { design }\end{array}$ & $\begin{array}{c}\text { Sample } \\
\text { size }\end{array}$ & Participants & & & & \\
\hline $\begin{array}{l}\text { Cha et al. } \\
\text { (2008a) }\end{array}$ & $\begin{array}{l}\text { Cross- } \\
\text { sectional, } \\
\text { correla- } \\
\text { tional } \\
\text { design }\end{array}$ & 351 & $\begin{array}{l}\text { Unmarried } \\
\text { students } \\
\text { aged } 18-25 \\
\text { years }\end{array}$ & $\begin{array}{l}\text { To validate the } \\
\text { psychometric properties } \\
\text { of the CSE }\end{array}$ & $\begin{array}{l}\text { Confidence to use } \\
\text { condoms, intention } \\
\text { of condom use, use } \\
\text { of condoms }\end{array}$ & $\begin{array}{l}\text { The CSE was shown to be an } \\
\text { appropriate instrument to access } \\
\text { youths' sexual behavior. The } \\
\text { findings revealed that participants } \\
\text { with high CSE-K scores showed } \\
\text { significantly higher scores for } \\
\text { intention to use condoms and a } \\
\text { higher rate of actual condom use. }\end{array}$ & $\begin{array}{l}\text { The CSE-K was a reliable and } \\
\text { valid measurement to } \\
\text { measure condom self-efficacy } \\
\text { among Korean college } \\
\text { students. }\end{array}$ \\
\hline $\begin{array}{l}\text { Cha et al. } \\
\text { (2007) }\end{array}$ & $\begin{array}{l}\text { Cross- } \\
\text { sectional, } \\
\text { correla- } \\
\text { tional } \\
\text { design }\end{array}$ & 170 & $\begin{array}{l}\text { Male } \\
\text { students } \\
\text { aged 18-25 } \\
\text { years }\end{array}$ & $\begin{array}{l}\text { To examine the mediating } \\
\text { effect of condom } \\
\text { self-efficacy between the } \\
\text { parent-adolescent } \\
\text { relationship and the } \\
\text { intention to use condoms }\end{array}$ & $\begin{array}{l}\text { Parent-adolescent } \\
\text { communication, } \\
\text { condom efficacy, } \\
\text { and intention of } \\
\text { condom use }\end{array}$ & $\begin{array}{l}\text { As a result of predicting the } \\
\text { intention to use condoms, there } \\
\text { was a direct association between } \\
\text { mother-son communication and } \\
\text { condom self-efficacy. However, } \\
\text { communication between father } \\
\text { and son had an indirect effect on } \\
\text { the intention to use condoms. }\end{array}$ & $\begin{array}{l}\text { When young students had good } \\
\text { relationships with their } \\
\text { parents, they were more likely } \\
\text { to intend to use condoms and } \\
\text { actually use condoms. Thus, } \\
\text { when developing condom } \\
\text { education programs, we } \\
\text { should consider } \\
\text { culture-specific, and } \\
\text { family-based aspects. }\end{array}$ \\
\hline $\begin{array}{l}\text { Cha et al. } \\
(2008 b)\end{array}$ & $\begin{array}{l}\text { Cross- } \\
\text { sectional, } \\
\text { correla- } \\
\text { tional } \\
\text { design }\end{array}$ & 298 & $\begin{array}{l}\text { College } \\
\text { students }\end{array}$ & $\begin{array}{l}\text { To examine the efficacy of } \\
\text { the TPB among college } \\
\text { students on intentions of } \\
\text { condom use }\end{array}$ & $\begin{array}{l}\text { Variables derived } \\
\text { from the TPB } \\
\text { (attitude, subjective } \\
\text { norm to use } \\
\text { condoms, perceived } \\
\text { behavioral control, } \\
\text { intention), } \\
\text { parent-adolescent } \\
\text { communication, and } \\
\text { perceived risk of } \\
\text { sexual behavior }\end{array}$ & $\begin{array}{l}\text { Older students had high condom } \\
\text { efficacy and relatively high } \\
\text { perception of peer norms for using } \\
\text { condoms. All TPB components } \\
\text { significantly predicted intention of } \\
\text { condom use for male students, but } \\
\text { only condom attitude and condom } \\
\text { efficacy for female students. Also, } \\
\text { the quality of parent-adolescent } \\
\text { communication significantly } \\
\text { predicted higher condom efficacy } \\
\text { only for male students. }\end{array}$ & $\begin{array}{l}\text { The TPB model was adequate } \\
\text { for explaining the intention to } \\
\text { use condoms among Korean } \\
\text { youths. However, this study } \\
\text { showed that condom } \\
\text { education programs for safer } \\
\text { sex need to be developed } \\
\text { differently by gender. }\end{array}$ \\
\hline Cho (2006) & $\begin{array}{l}\text { Quasi- } \\
\text { experi- } \\
\text { mental } \\
\text { design }\end{array}$ & 94 & $\begin{array}{l}\text { College } \\
\text { students }\end{array}$ & $\begin{array}{l}\text { To identify the effect of } \\
\text { sexual health education } \\
\text { through dramaturgical } \\
\text { interaction on attitudes } \\
\text { and intentions to use } \\
\text { condoms }\end{array}$ & $\begin{array}{l}\text { Condom attitudes } \\
\text { Condom use intention }\end{array}$ & $\begin{array}{l}\text { Female participants showed } \\
\text { significant positive changes in } \\
\text { reliability and effectiveness and } \\
\text { embarrassment about negotiation } \\
\text { and use. No significant difference } \\
\text { was found in intention to use } \\
\text { condoms. }\end{array}$ & $\begin{array}{l}\text { Sexual education should } \\
\text { include both men and women, } \\
\text { and target both cognitive and } \\
\text { behavioral aspect among } \\
\text { young adults within the } \\
\text { community. }\end{array}$ \\
\hline $\begin{array}{l}\text { Cho et al. } \\
(2009)\end{array}$ & $\begin{array}{l}\text { Cross- } \\
\text { sectional, } \\
\text { correla- } \\
\text { tional } \\
\text { design }\end{array}$ & 349 & $\begin{array}{l}\text { College } \\
\text { students }\end{array}$ & $\begin{array}{l}\text { To identify sexual } \\
\text { behavior and predictors } \\
\text { of condom attitudes by } \\
\text { measuring the attitudes, } \\
\text { self-efficacy, knowledge, } \\
\text { and perceived risk of } \\
\text { condom use in sexual } \\
\text { relationships }\end{array}$ & $\begin{array}{l}\text { Attitudes, } \\
\text { self-efficacy, } \\
\text { knowledge, } \\
\text { perceived risk of } \\
\text { condom use }\end{array}$ & $\begin{array}{l}\text { Predictors of condom use were } \\
\text { gender, condom use experience, } \\
\text { pregnancy experience, smoking, } \\
\text { and self-efficacy. In other words, } \\
\text { female students, those always } \\
\text { using condoms, no pregnancy } \\
\text { experience, and those with higher } \\
\text { self-efficacy for using condoms } \\
\text { showed more positive attitudes. }\end{array}$ & $\begin{array}{l}\text { Male students, those with no } \\
\text { experience of using condoms, } \\
\text { and non-smokers had low } \\
\text { condom use attitude scores, } \\
\text { indicating negative attitudes } \\
\text { toward condom use. } \\
\text { Therefore, sex education for } \\
\text { them is necessary. }\end{array}$ \\
\hline $\begin{array}{l}\text { Hur and Cho } \\
\text { (2007) }\end{array}$ & $\begin{array}{l}\text { Mixed- } \\
\text { method } \\
\text { study }\end{array}$ & 186 & $\begin{array}{l}\text { College } \\
\text { students }\end{array}$ & $\begin{array}{l}\text { To categorize } \\
\text { condom-negotiation } \\
\text { strategies and } \\
\text { preferences of Korean } \\
\text { college students and } \\
\text { examine the relationship } \\
\text { between strategies and } \\
\text { other sex-related } \\
\text { concepts }\end{array}$ & $\begin{array}{l}\text { Perceived behavioral } \\
\text { control in condom } \\
\text { use, condom-related } \\
\text { attitudes, subjective } \\
\text { norms, intention of } \\
\text { condom use, } \\
\text { condom negotiation } \\
\text { strategies }\end{array}$ & $\begin{array}{l}\text { Seven types of persuasion strategies } \\
\text { for condom use and six types of } \\
\text { persuasion strategies for condom } \\
\text { avoidance were abstracted. } \\
\text { Condom attitudes and intention } \\
\text { were positively correlated with } \\
\text { withholding sex strategies. }\end{array}$ & $\begin{array}{l}\text { It is necessary to strengthen } \\
\text { condom negotiation strategies } \\
\text { to protect oneself from others } \\
\text { rather than focusing on ethical } \\
\text { content in sex education. }\end{array}$ \\
\hline $\begin{array}{l}\text { Hur et al. } \\
(2004)\end{array}$ & $\begin{array}{l}\text { Cross- } \\
\text { sectional, } \\
\text { correla- } \\
\text { tional } \\
\text { design }\end{array}$ & 201 & $\begin{array}{l}\text { College } \\
\text { students }\end{array}$ & $\begin{array}{l}\text { To investigate the gender } \\
\text { differences of risk-taking } \\
\text { decisions making in } \\
\text { sexual behaviors, } \\
\text { particularly condom use } \\
\text { during sexual intercourse }\end{array}$ & $\begin{array}{l}\text { Perceived behavioral } \\
\text { control in condom } \\
\text { use, condom-related } \\
\text { attitudes, subjective } \\
\text { norms, intention of } \\
\text { condom use }\end{array}$ & $\begin{array}{l}\text { Condom-related attitudes, } \\
\text { subjective norms, and perceived } \\
\text { controllability were found to } \\
\text { significantly influence intention of } \\
\text { condom use, while perceived } \\
\text { controllability only influenced } \\
\text { intention in males. }\end{array}$ & $\begin{array}{l}\text { The results showed that } \\
\text { attitudes, norms, and control } \\
\text { all influenced intention, as in } \\
\text { the TPB. In particular, it was } \\
\text { confirmed that there were } \\
\text { differences in factors affecting } \\
\text { intention according to gender. }\end{array}$ \\
\hline
\end{tabular}

AIDS, acquired immune deficiency syndrome; CSE, condom self-efficacy scale; CSE-K, condom self-efficacy scale-Korean; CSS, confidence in safer sex; ECP, emergency contraceptive pills; HPV, human papillomavirus; STI, sexually transmitted infection; TPB, theory of planned behavior; TTM, trans-theoretical model. 
Table 3. Summary of Studies Included in the Integrative Review (Continued) $(N=20)$

\begin{tabular}{|c|c|c|c|c|c|c|c|}
\hline \multirow[b]{2}{*}{$\begin{array}{l}\text { Author } \\
\text { (year) }\end{array}$} & \multicolumn{3}{|c|}{ Design } & \multirow[b]{2}{*}{ Purpose } & \multirow[b]{2}{*}{$\begin{array}{l}\text { Outcome } \\
\text { variables }\end{array}$} & \multirow[b]{2}{*}{ Key findings } & \multirow[b]{2}{*}{ Implications } \\
\hline & $\begin{array}{l}\text { Research } \\
\text { design }\end{array}$ & $\begin{array}{l}\text { Sample } \\
\text { size }\end{array}$ & Participants & & & & \\
\hline $\begin{array}{l}\text { Jeong and } \\
\text { Kim (2018) }\end{array}$ & $\begin{array}{l}\text { Method- } \\
\text { ological } \\
\text { design }\end{array}$ & 163 & $\begin{array}{l}\text { College } \\
\text { students }\end{array}$ & $\begin{array}{l}\text { To examine the } \\
\text { validity and } \\
\text { reliability of the } \\
\text { developed } \\
\text { instrument and to } \\
\text { measure the benefits } \\
\text { of condom use, } \\
\text { barriers, and } \\
\text { self-efficacy among } \\
\text { health belief factors }\end{array}$ & Condom use beliefs & $\begin{array}{l}\text { The developed instrument is proposed } \\
\text { to be useful to measure condom-use } \\
\text { beliefs for college students in Korea. }\end{array}$ & $\begin{array}{l}\text { This instrument is considered to be } \\
\text { useful to measure the } \\
\text { condom-use beliefs of Korean } \\
\text { undergraduate students. It can be } \\
\text { used to measure the effectiveness } \\
\text { of future interventions. }\end{array}$ \\
\hline $\begin{array}{l}\text { Jun and Shin } \\
\text { (2016) }\end{array}$ & $\begin{array}{l}\text { Cross- } \\
\text { sectional, } \\
\text { correla- } \\
\text { tional } \\
\text { design }\end{array}$ & 156 & $\begin{array}{l}\text { Male college } \\
\text { students }\end{array}$ & $\begin{array}{l}\text { To examine the factors } \\
\text { that influence } \\
\text { condom use } \\
\text { targeting male } \\
\text { college students }\end{array}$ & $\begin{array}{l}\text { Sex-role attitudes, } \\
\text { sexual attitudes, } \\
\text { sexual knowledge, } \\
\text { AIDS knowledge, } \\
\text { sexual autonomy, } \\
\text { condom use }\end{array}$ & $\begin{array}{l}\text { Levels of condom use of participants } \\
\text { were identified by number of dates, } \\
\text { number of sex partners, and sexual } \\
\text { attitudes. Condom use had a significant } \\
\text { positive correlation with sexual } \\
\text { attitudes. } \\
\text { The more positive the sexual attitudes, } \\
\text { the greater number of dates, and the } \\
\text { fewer sexual partners, the more } \\
\text { condom use. }\end{array}$ & $\begin{array}{l}\text { When planning sex education } \\
\text { among male students, it is } \\
\text { necessary to include content that } \\
\text { can form a positive sexual } \\
\text { attitude. This will increase the } \\
\text { use of condoms. }\end{array}$ \\
\hline $\begin{array}{l}\text { Kang and } \\
\text { Chang } \\
(2004)\end{array}$ & $\begin{array}{l}\text { Method- } \\
\text { ological } \\
\text { design }\end{array}$ & 631 & $\begin{array}{l}\text { College } \\
\text { students } \\
\text { who have } \\
\text { had sexual } \\
\text { experience } \\
\text { over the } \\
\text { past year }\end{array}$ & $\begin{array}{l}\text { To design and } \\
\text { evaluate a scale to } \\
\text { measure attitudes } \\
\text { toward condom use } \\
\text { in a sexual } \\
\text { relationship }\end{array}$ & Condom attitudes & $\begin{array}{l}\text { The Condom Attitude Scale developed } \\
\text { by authors was shown to be an } \\
\text { appropriate instrument to access } \\
\text { youth's condom attitudes. The scale is } \\
\text { composed of three factors: interruption } \\
\text { of sexual pleasure; protection; and } \\
\text { image. Consistent condom users had } \\
\text { more positive condom attitudes. }\end{array}$ & $\begin{array}{l}\text { The Condom Attitude Scale was a } \\
\text { reliable and valid instrument to } \\
\text { measure attitudes toward } \\
\text { condom among Korean college } \\
\text { students. }\end{array}$ \\
\hline $\begin{array}{l}\text { Kang and } \\
\text { Moneyham } \\
(2008)\end{array}$ & $\begin{array}{l}\text { Cross- } \\
\text { sectional, } \\
\text { correla- } \\
\text { tional } \\
\text { design }\end{array}$ & 1,046 & $\begin{array}{l}\text { College } \\
\text { students }\end{array}$ & $\begin{array}{l}\text { To examine the } \\
\text { intentions, } \\
\text { knowledge, and } \\
\text { attitudes of college } \\
\text { students on the use } \\
\text { of ECPs and } \\
\text { condoms }\end{array}$ & $\begin{array}{l}\text { Intent to use ECPs and } \\
\text { condoms, knowledge } \\
\text { about ECPs, and } \\
\text { attitudes toward } \\
\text { ECPs and condoms }\end{array}$ & $\begin{array}{l}\text { College students have lack of knowledge } \\
\text { of ECPs and misconception about the } \\
\text { safety of their use. Accurate } \\
\text { information is important in changing } \\
\text { attitudes toward ECPs and condoms. } \\
\text { The intention to use ECP correlated } \\
\text { with the intention to use condoms and } \\
\text { with attitudes toward condoms. }\end{array}$ & $\begin{array}{l}\text { Efforts are needed to disseminate } \\
\text { the latest information to the } \\
\text { students and develop education } \\
\text { to enable youths to make } \\
\text { informed decisions on use of } \\
\text { ECPs and condoms. }\end{array}$ \\
\hline $\begin{array}{l}\text { Kang and } \\
\text { Moneyham } \\
(2010)\end{array}$ & $\begin{array}{l}\text { Cross- } \\
\text { sectional, } \\
\text { correla- } \\
\text { tional } \\
\text { design }\end{array}$ & 1,359 & $\begin{array}{l}\text { Female } \\
\text { college } \\
\text { students }\end{array}$ & $\begin{array}{l}\text { To evaluate the } \\
\text { attitudes toward and } \\
\text { intention to receive } \\
\text { HPV vaccination and } \\
\text { intention of condom } \\
\text { use and investigate } \\
\text { the relationships } \\
\text { among the variables }\end{array}$ & $\begin{array}{l}\text { Attitudes toward the } \\
\text { HPV vaccine, } \\
\text { intention to receive } \\
\text { HPV vaccination, } \\
\text { and intention to use } \\
\text { condoms }\end{array}$ & $\begin{array}{l}\text { Most young women did not receive the } \\
\text { HPV vaccine and were not willing to } \\
\text { get vaccinated. However, the } \\
\text { willingness for vaccination was highest } \\
\text { when it was recommended by } \\
\text { clinicians. } \\
\text { Positive attitudes towards the HPV } \\
\text { vaccine were significantly correlated } \\
\text { with the intention to get vaccinated. }\end{array}$ & $\begin{array}{l}\text { Efforts are needed to disseminate } \\
\text { accurate information about the } \\
\text { vaccine because intention for } \\
\text { HPV vaccination was less when } \\
\text { attitudes to HPV vaccines were } \\
\text { negative because of the } \\
\text { perception that they could lead to } \\
\text { unsafe or dangerous sexual } \\
\text { behavior. }\end{array}$ \\
\hline $\begin{array}{l}\text { Kwon and } \\
\text { Lee (2018) }\end{array}$ & $\begin{array}{l}\text { Cross- } \\
\text { sectional, } \\
\text { correla- } \\
\text { tional } \\
\text { design }\end{array}$ & 323 & $\begin{array}{l}\text { Male college } \\
\text { students }\end{array}$ & $\begin{array}{l}\text { To explore how AIDS } \\
\text { knowledge, } \\
\text { self-esteem, sense of } \\
\text { control, and } \\
\text { optimism bias affect } \\
\text { condom use among } \\
\text { male college } \\
\text { students }\end{array}$ & $\begin{array}{l}\text { Condom use, AIDS } \\
\text { knowledge, } \\
\text { self-esteem, sense of } \\
\text { control, and } \\
\text { optimism bias }\end{array}$ & $\begin{array}{l}\text { The results indicate that self-esteem and } \\
\text { sense of control were predictors of } \\
\text { condom use in the group of } \\
\text { participants who engaged in sexual } \\
\text { intercourse with steady sexual } \\
\text { partners. }\end{array}$ & $\begin{array}{l}\text { In this study, sense of control was } \\
\text { examined by questions about } \\
\text { prevention of AIDS and control } \\
\text { of unhealthy sexual life. The } \\
\text { results show the importance of } \\
\text { education and training to enable } \\
\text { students to gain a sense of control } \\
\text { such as controlling their own } \\
\text { prevention of AIDS and sexual } \\
\text { activity. This will have a positive } \\
\text { impact on the use of condoms. }\end{array}$ \\
\hline $\begin{array}{l}\text { Kwon et al. } \\
(2008)\end{array}$ & $\begin{array}{l}\text { Cross- } \\
\text { sectional, } \\
\text { correla- } \\
\text { tional } \\
\text { design }\end{array}$ & 1,250 & $\begin{array}{l}\text { Unmarried } \\
\text { college } \\
\text { students }\end{array}$ & $\begin{array}{l}\text { Utilized TTM to } \\
\text { investigate condom } \\
\text { use among college } \\
\text { students }\end{array}$ & $\begin{array}{l}\text { Decisional balance, } \\
\text { confidence in safer } \\
\text { sex, and temptation } \\
\text { for unprotected sex, } \\
\text { stage of change } \\
\text { algorithm }\end{array}$ & $\begin{array}{l}\text { The results indicate that age (juniors), a } \\
\text { positive attitude toward condom use } \\
\text { (pro), and side effects on CSS are } \\
\text { associated with condom use. }\end{array}$ & $\begin{array}{l}\text { Sex educators and programs } \\
\text { should consider including } \\
\text { population-targeted sexual } \\
\text { culture context when creating } \\
\text { intervention plans to increase } \\
\text { youths' practice of safe sex. }\end{array}$ \\
\hline
\end{tabular}

AIDS, acquired immune deficiency syndrome; CSE, condom self-efficacy scale; CSE-K, condom self-efficacy scale-Korean; CSS, confidence in safer sex; ECP, emergency contraceptive pills; HPV, human papillomavirus; STI, sexually transmitted infection; TPB, theory of planned behavior; TTM, trans-theoretical model. 
Table 3. Summary of Studies Included in the Integrative Review (Continued) $(N=20)$

\begin{tabular}{|c|c|c|c|c|c|c|c|}
\hline \multirow[b]{2}{*}{$\begin{array}{l}\text { Author } \\
\text { (year) }\end{array}$} & \multicolumn{3}{|c|}{ Design } & \multirow[b]{2}{*}{ Purpose } & \multirow[b]{2}{*}{$\begin{array}{l}\text { Outcome } \\
\text { variables }\end{array}$} & \multirow[b]{2}{*}{ Key findings } & \multirow[b]{2}{*}{ Implications } \\
\hline & $\begin{array}{c}\text { Research } \\
\text { design }\end{array}$ & $\begin{array}{c}\text { Sample } \\
\text { size }\end{array}$ & Participants & & & & \\
\hline Lee (2010) & $\begin{array}{l}\text { Cross- } \\
\text { sectional, } \\
\text { correla- } \\
\text { tional } \\
\text { design }\end{array}$ & 399 & $\begin{array}{l}\text { Male college } \\
\text { students }\end{array}$ & $\begin{array}{l}\text { To analyze predictors } \\
\text { of condom use } \\
\text { intention according } \\
\text { to experience of } \\
\text { sexual intercourse }\end{array}$ & $\begin{array}{l}\text { Condom use } \\
\text { intentions } \\
\text { Susceptibility to } \\
\text { STIs/AIDS, } \\
\text { pregnancy } \\
\text { Benefits from condom } \\
\text { use, barriers to } \\
\text { condom use, condom } \\
\text { self-efficacy, and } \\
\text { subjective norms }\end{array}$ & $\begin{array}{l}\text { The results indicate that susceptibility to } \\
\text { STIs/AIDS and pregnancy and benefits } \\
\text { of condom use were predictors of } \\
\text { condom use intentions in the } \\
\text { non-experienced group. } \\
\text { The factors that predict the intention to } \\
\text { condom use in the experienced group } \\
\text { were barriers to use and condom use } \\
\text { self-efficacy. }\end{array}$ & $\begin{array}{l}\text { Since the factors that influence the } \\
\text { intention to use condoms differ } \\
\text { by experience of condom use, } \\
\text { programs should be provided for } \\
\text { each group. Also, it is important } \\
\text { to educate young people about } \\
\text { susceptibility to STIs/AIDS and } \\
\text { pregnancy before using condoms } \\
\text { to increase condom use intention. }\end{array}$ \\
\hline $\begin{array}{l}\text { Park and Han } \\
\quad(2000)\end{array}$ & $\begin{array}{l}\text { Cross- } \\
\text { sectional, } \\
\text { correla- } \\
\text { tional } \\
\text { design }\end{array}$ & 999 & $\begin{array}{l}\text { Male college } \\
\text { students }\end{array}$ & $\begin{array}{l}\text { To measure attitudes } \\
\text { and knowledge } \\
\text { about condom use, } \\
\text { and the factors } \\
\text { influencing the } \\
\text { preference to use } \\
\text { condoms. }\end{array}$ & $\begin{array}{l}\text { Preference for } \\
\text { condoms, knowledge } \\
\text { and attitudes toward } \\
\text { condom use }\end{array}$ & $\begin{array}{l}\text { The results of this study indicate that } \\
\text { positive attitudes and higher } \\
\text { knowledge of condom use, experience } \\
\text { of condom use, completion of military } \\
\text { service, non-experience of sexual } \\
\text { intercourse in the last } 6 \text { months, and } \\
\text { frequent contact with information on } \\
\text { condom use were associated with a } \\
\text { preference for condoms. }\end{array}$ & $\begin{array}{l}\text { Efforts are needed to increase } \\
\text { opportunities for access to } \\
\text { information about condoms, } \\
\text { which should increase condom } \\
\text { preference along with increased } \\
\text { knowledge and attitudes. }\end{array}$ \\
\hline $\begin{array}{l}\text { Park and Lim } \\
\quad(2002)\end{array}$ & $\begin{array}{l}\text { Cross- } \\
\text { sectional, } \\
\text { correla- } \\
\text { tional } \\
\text { design }\end{array}$ & 370 & $\begin{array}{l}\text { Unmarried } \\
\text { male } \\
\text { college } \\
\text { students }\end{array}$ & $\begin{array}{l}\text { To analyze the factors } \\
\text { influencing } \\
\text { self-confidence for } \\
\text { using condoms. }\end{array}$ & $\begin{array}{l}\text { Self-confidence of } \\
\text { using condoms, } \\
\text { attitudes and } \\
\text { knowledge about } \\
\text { condoms and } \\
\text { STIs/AIDS, } \\
\text { misconceptions } \\
\text { about preventing } \\
\text { STIs }\end{array}$ & $\begin{array}{l}\text { The results of this study indicate that age } \\
\text { (older), experience of condom use in } \\
\text { the last } 1 \text { year, and positive attitudes } \\
\text { toward condoms affected } \\
\text { self-confidence of using condoms. }\end{array}$ & $\begin{array}{l}\text { Efforts are needed to create } \\
\text { programs to enable youths to } \\
\text { gain positive attitudes and } \\
\text { increase self-confidence inf using } \\
\text { condoms. }\end{array}$ \\
\hline $\begin{array}{l}\text { Park et al. } \\
\text { (2003) }\end{array}$ & $\begin{array}{l}\text { Cross- } \\
\text { sectional } \\
\text { and } \\
\text { correla- } \\
\text { tional } \\
\text { design }\end{array}$ & 946 & $\begin{array}{l}\text { Unmarried } \\
\text { male } \\
\text { college } \\
\text { students }\end{array}$ & $\begin{array}{l}\text { To measure the } \\
\text { attitudes and } \\
\text { knowledge about } \\
\text { condom use, AIDS, } \\
\text { and the factors } \\
\text { influencing attitudes } \\
\text { in male students }\end{array}$ & $\begin{array}{l}\text { Attitudes and } \\
\text { knowledge toward } \\
\text { condoms, and } \\
\text { knowledge and } \\
\text { severity of AIDS }\end{array}$ & $\begin{array}{l}\text { The results of this study showed that } \\
\text { older age, experience of condom use, } \\
\text { and knowledge about AIDS positively } \\
\text { affected attitudes toward condoms. }\end{array}$ & $\begin{array}{l}\text { Efforts are needed to inculcate } \\
\text { positive attitudes toward } \\
\text { condoms for young male } \\
\text { students, non-condom users, and } \\
\text { education about AIDS is also } \\
\text { needed to increase positive } \\
\text { attitudes toward condoms. }\end{array}$ \\
\hline $\begin{array}{l}\text { Park et al. } \\
\text { (2002) }\end{array}$ & $\begin{array}{l}\text { Cross- } \\
\text { sectional } \\
\text { descrip- } \\
\text { tive study }\end{array}$ & 946 & $\begin{array}{l}\text { Unmarried } \\
\text { male } \\
\text { college } \\
\text { students }\end{array}$ & $\begin{array}{l}\text { To measure the } \\
\text { attitudes toward } \\
\text { condom use and } \\
\text { knowledge of } \\
\text { STIs/AIDS in male } \\
\text { college students }\end{array}$ & $\begin{array}{l}\text { Intent to use condoms, } \\
\text { condom and } \\
\text { STIs/AIDS attitudes } \\
\text { and knowledge, } \\
\text { perceived } \\
\text { susceptibility to and } \\
\text { severity of } \\
\text { STIs/AIDS }\end{array}$ & $\begin{array}{l}\text { Those with condom experience showed } \\
\text { more positive attitudes than those } \\
\text { without condom experience, and the } \\
\text { perceived susceptibility to and severity } \\
\text { of STIs/ AIDS were not different } \\
\text { according to experiences of condom } \\
\text { use. No difference in knowledge about } \\
\text { STIs/AIDS was found by experience of } \\
\text { condom use. }\end{array}$ & $\begin{array}{l}\text { Efforts are needed to inculcate } \\
\text { positive attitudes about condoms } \\
\text { that might increase the use of } \\
\text { condoms. }\end{array}$ \\
\hline $\begin{array}{l}\text { Sohn and } \\
\text { Chun (2007) }\end{array}$ & $\begin{array}{l}\text { Secondary } \\
\text { data } \\
\text { analysis }\end{array}$ & 501 & $\begin{array}{l}\text { Single, aged } \\
19-30 \text { years }\end{array}$ & $\begin{array}{l}\text { To examine gender } \\
\text { differences in sexual } \\
\text { behavior, } \\
\text { condom-related } \\
\text { behavior, and } \\
\text { attitudes including } \\
\text { perceived benefits, } \\
\text { perceived barriers, } \\
\text { and self-efficacy } \\
\text { towards condom } \\
\text { use. }\end{array}$ & $\begin{array}{l}\text { Behavior and attitudes } \\
\text { toward AIDS such as } \\
\text { perceived benefits, } \\
\text { perceived barriers, } \\
\text { and self-efficacy } \\
\text { toward condom use }\end{array}$ & $\begin{array}{l}\text { Male initiated sexual behavior earlier } \\
\text { and had more multiple partners than } \\
\text { female, but both genders were equally } \\
\text { likely to have inconsistent use of } \\
\text { condom. Male also more perceived } \\
\text { benefits and a higher level of } \\
\text { self-efficacy in condom use than } \\
\text { female, and male agreed that using } \\
\text { condoms would reduce sexual } \\
\text { pleasure, is troublesome, and is less } \\
\text { exciting or romantic. }\end{array}$ & $\begin{array}{l}\text { Sex education programs for young } \\
\text { men and women, particularly } \\
\text { those related to HIV prevention } \\
\text { and sexual health, should focus } \\
\text { on reducing perceived barriers in } \\
\text { condom use. Especially for } \\
\text { women, self-efficacy in condom } \\
\text { use should be included. }\end{array}$ \\
\hline
\end{tabular}

AIDS, acquired immune deficiency syndrome; CSE, condom self-efficacy scale; CSE-K, condom self-efficacy scale-Korean; CSS, confidence in safer sex; ECP, emergency contraceptive pills; $\mathrm{HPV}$, human papillomavirus; STI, sexually transmitted infection; TPB, theory of planned behavior; TTM, trans-theoretical model.

ciated with the predicted intention of condom use among male students, but only attitudes and condom efficacy were significant for female students [A3]. Women had higher ECP knowledge, intention for ECP use, and intention for condom use than men, and had a positive attitude toward condoms [A5,A12]. However, another study found men to have greater perceived benefits and a higher level of self-efficacy in condom use than women [A20]. Perceived control also influenced condom use intention in male students who expressed condom use intention [A7]. Furthermore, a higher degree of knowledge related to condoms was associated with higher preference for and intention of condom use [A15,A16,A18]. In 
Table 4. Variables and Instruments in the Integrative Review $(N=20)$

\begin{tabular}{|c|c|c|}
\hline Variables & & Instrument [article number] $^{*}$ \\
\hline \multirow[t]{5}{*}{$\begin{array}{l}\text { Condom-related } \\
\text { factors }\end{array}$} & Use of condoms & $\begin{array}{l}\text { Condom use questionnaire [A13] } \\
\text { Other questionnaire developed by authors [A1,A2,A9,A11] }\end{array}$ \\
\hline & Attitudes & $\begin{array}{l}\text { CAS [A3,A10] } \\
\text { College students's condom attitude scale [A5,A11] } \\
\text { Other questionnaire developed by authors [A6,A7,A16-A19] } \\
\text { UCLA MCAS [A4] }\end{array}$ \\
\hline & Knowledge & $\begin{array}{l}\text { Benefits of condom use and barriers to condom use [A15] } \\
\text { Knowledge about condoms [A5] } \\
\text { Other questionnaire developed by authors [A16,A18] }\end{array}$ \\
\hline & $\begin{array}{l}\text { Condom efficacy } \\
\text { and self-confidence }\end{array}$ & $\begin{array}{l}\text { CSE-K [A1] } \\
\text { Condom use self-efficacy scale [A5] } \\
\text { Condom self-efficacy scale [A2, A3] } \\
\text { Condom self-efficacy scale [A15] } \\
\text { Condom self-efficacy measure [A13] } \\
\text { Other questionnaire developed by authors [A6,A7,A13,A17] } \\
\text { SES [A13] } \\
\text { The benefits, barriers, and self-efficacy measurement tool [A8] }\end{array}$ \\
\hline & $\begin{array}{l}\text { Intention and } \\
\text { preference }\end{array}$ & $\begin{array}{l}\text { Intention of sexual behavior scale [A1-A3] } \\
\text { Other questionnaire developed by authors [A6,A7,A12,A15,A16,A19] } \\
\text { Intention to use a condom scale [A4] }\end{array}$ \\
\hline \multirow[t]{4}{*}{$\begin{array}{l}\text { Factors related to } \\
\text { non-condom- } \\
\text { related knowledge } \\
\text { and attitudes }\end{array}$} & Sexual behavior & $\begin{array}{l}\text { Sex-role attitude scale [A9] } \\
\text { Sexual attitude scale [A9] } \\
\text { Sexual autonomy scale [A9] } \\
\text { Sexual knowledge scale [A9] } \\
\text { Perceived risk of sexual behavior questionnaire [A5] } \\
\text { Perceived risk of sexual behavior questionnaire developed by authors [A3] }\end{array}$ \\
\hline & ECP & $\begin{array}{l}\text { Intent to use ECP question developed by authors [A11] } \\
\text { ECP attitude scale [A11] }\end{array}$ \\
\hline & STIs/AIDS & $\begin{array}{l}\text { AIDS knowledge questionnaire [A13] } \\
\text { AIDS knowledge questionnaire [A9] } \\
\text { Attitude and behaviors toward AIDS [A20] } \\
\text { Knowledge of AIDS questionnaire developed by authors [A17,A18] } \\
\text { Knowledge of STIs/AIDS questionnaire developed by authors [A19] } \\
\text { Knowledge-on-ECPs scale [A11] } \\
\text { Misconceptions about protective STI fact sheet [A17] } \\
\text { Other perceived severity to STIs/AIDS questionnaire developed by authors [A17-A19] } \\
\text { Susceptibility to STIs/AIDs \& pregnancy scale[A15] }\end{array}$ \\
\hline & HPV vaccine & $\begin{array}{l}\text { HPV attitude questionnaire developed by the authors [A12] } \\
\text { Intent to get HPV vaccinated developed by the author [A12] }\end{array}$ \\
\hline \multirow[t]{3}{*}{ Others } & Communication & Parent-adolescent communication scale $[\mathrm{A} 2, \mathrm{~A} 3]$ \\
\hline & Optimism bias & Optimistic bias scale [A13] \\
\hline & Subjective norms & $\begin{array}{l}\text { Subjective norm questionnaire [A15] } \\
\text { SRBBS [A3] } \\
\text { Other questionnaire developed by authors [A6,A7] }\end{array}$ \\
\hline
\end{tabular}

*Article number derived from Table 1; AIDS, acquired immune deficiency syndrome; CAS, condom attitude scale; CSE-K, condom self-efficacy scale-Korean; ECP, emergency contraceptive pills; HPV, human papillomavirus; SES, self-efficacy scale; SRBBS, sexual risk behavior belief and self-efficacy scale; STI, sexually transmitted infection; UCLA MCAS, The University of California at Los Angeles multidimensional condom attitude scale. 
this regard, more positive sexual attitudes were associated with higher levels of condom use [A9]. This result suggests that improving gender attitudes and sexual knowledge can increase the degree of condom use among male and female college students.

\section{DISCUSSION}

The purpose of this study was to provide evidence for effective nursing education by analyzing and evaluating the characteristics and content of studies of condom use in Korean college students.

Most of the studies were published more than 5 years ago, and recent studies have not investigated this issue actively. Perceptions of sex have changed as generations have shifted, and in fact the incidence of STIs in young adults has increased more than in the past [A8]. This means that as the perceptions, attitudes, and knowledge of young adults may have changed, up-to-date research is needed. In addition, the most common contraceptive method used by Koreans in their 20s was condoms, underscoring the need for research on the use of condoms [25]. Therefore, this study examined condom use among Korean college students in order to suggest directions for future research through an integrative review.

Many of the studies examined used questionnaires developed by the researchers to measure variables such as condom use attitudes and knowledge, self-efficacy, confidence, and intention towards condom use. Thus, these questionnaires do not have proven reliability and validity. For accurate measurements, it is necessary to develop a relevant instrument and to verify its reliability and validity before use. Three studies developed and applied condom-related instruments in the Korean language [A1,A8,A10]. It is essential to consider Korea-specific aspects of culture because sexual culture, including the occurrence and prevention of STIs, varies considerably across ethnicities and cultural settings [26,27]. Therefore, in addition to the instruments that have been developed, Korean versions of more instruments need to be developed to help identify the effects of sex education interventions for Koreans.

The variables measured included factors related to condoms, as well as knowledge and attitudes about sexual behavior, ECP, and STIs/AIDS, all of which may affect condom use. First, questions on attitudes, knowledge, confidence, and intention to use condoms were asked, along with whether respondents in fact used condoms. As a result, condom attitudes, knowledge, and self-efficacy were found to be factors related to condom use that influenced individuals' health beliefs [27]. Although studies used questionnaires on health beliefs that measured factors related to condom use, direct in- vestigations of condom use are lacking. Therefore, further research should use questionnaires to directly confirm the use of condoms.

In this study, the indirect factors of sexual behavior, emergency contraceptives, and STIs/AIDS were considered to be threats perceived by college students [A3,A5,A15,A17-19]. These factors measured the degree to which students perceived the risks they face if condoms are not used. According to a survey of Koreans in their 20s, one of the reasons for not using contraception was the idea that becoming pregnant is not easy [25]. These variables also influence health beliefs, which in turn later influence health behavior [27]. Therefore, health beliefs should be taken into account when developing education related to the use of condoms.

One of the measured variables, communication between parents and children, was a significant factor for self-efficacy towards condom use among male students [A3]. This is similar to the findings of a study of Korean students [A13] that the incidence of STIs among male adolescents who did not live with their parents was high. Parents and adolescents should be fully communicative, and having adequate discussions of sex will ensure that adolescents are prepared for sexual activity. To achieve this goal, parental education will be required in the future so that parents can feel free to talk with their children about sex.

One of the important findings of this study concerned the differences between male and female respondents in condom use and related factors. Likewise, only one intervention study presented the results of sexual education in a 5-week lecture with group discussions [A4]. The results of that study showed that only female students showed a significant effect with respect to the reliability and effectiveness of condoms and the embarrassment associated with condom negotiations and use on the condom subscale. There was, however, no significant change in condom use intention [A4]. Thus, there was a difference between men and women even though both genders received the same education. Similarly, the reviewed studies showed differences between men and women in relation to sexual behavior [A3,A20], similarly to previous studies of sex-related health beliefs and sexual activity in adolescents regarding their attitudes, knowledge, and actual sexual activity [27]. In a study of unmarried Korean men and women in their 20s, contraception self-efficacy was a significant contributing factor to contraception behavior, but its effect was significantly higher in women [28]. This suggests that there are similarities between men and women, but also differences that affect the use of condoms. Therefore, future interventions must consider gender differences and factors that may affect the actual use of condoms.

College students, who are in early adulthood, are sexually 
active and at a high risk of exposure to STIs [A8]. The most effective STI prevention method is the use of condoms. Research on how condoms are approached in current sexual education is inadequate. For example, only one of the 20 studies was an intervention study. A recent survey of Koreans in their 20s found the following reasons for not using contraception: first, respondents stated that it was inconvenient to use contraceptive devices such as condoms; second, respondents expressed difficulty in preparing for contraception use; third, respondents' partners did not want to use contraception; and fourth, it did not seem easy to become pregnant [25]. These barriers to condom use should be overcome through proper education. Moreover, education on the use of condoms is a leading demand of college students [29]. Therefore, there is an urgent need for educational interventions involving specific content about condoms reflecting the current situation in Korea.

Based on the results of this study, the following aspects should be considered in education. First, the content of education should address direct factors (e.g., condom-related factors) as well as knowledge and attitudes related to STIs and contraception in order to have a positive effect on health beliefs. It is hoped that college students will become aware of the dangers of unwanted pregnancies and STIs, thereby creating a positive perception of condom use and further promoting healthy and safe sex. Such programs will ultimately have a positive effect on condom use. Education about condoms should first target college students, and at least at present, separate and specific interventions should be conducted considering the characteristics of each gender. Adolescents and their parents should also be educated to promote condom use in adulthood.

\section{CONCLUSION}

This integrative review analyzed 20 studies of condom use among Korean college students and identified a lack of active research on this subject within the past 5 years. Many studies of condom use utilized questionnaires without established reliability and validity. In addition, condom use, intention, attitudes, knowledge, confidence, communication, subjective norms, and related factors such as perceived risk (e.g., sexual behavior, ECP, STIs/AIDS) were measured as variables related to condoms.

This study identified recent research trends, measurement variables and instruments, and the implications of studies, based on which we suggest the following steps to improve condom use among college students. First, an up-to-date survey of college students' condom use is needed. Second, an instrument should be developed reflecting Korean culture to measure the effectiveness of education on condom use. Third, gender-based education on condom use is needed. Lastly, sexual education should address condom use, the most effective method to prevent STIs, including related risk factors. When education related to condom use is provided, it should include factors directly related to condoms and background factors (knowledge and attitudes) that may indirectly affect condom use, such as knowledge and attitude about STIs, pregnancy, and contraception. Moreover, to increase the use of condoms by college students, it is suggested to target male and female college students, as well as adolescents and their parents. Such educational interventions will be helpful directly and indirectly, and are ultimately expected to increase the use of condoms by college students.

\section{Conflict of interest}

No existing or potential conflict of interest relevant to this article was reported.

\section{Data availability}

Please contact the corresponding author for data availability.

\section{REFERENCES}

1. Meena JK, Verma A, Kishore J, Ingle GK. Sexual and reproductive health: Knowledge, attitude, and perceptions among young unmarried male residents of Delhi. International Journal of Reproductive Medicine. 2015;2015:431460.

https://doi.org/10.1155/2015/431460

2. Goldenberg D, Telzer EH, Lieberman MD, Fuligni A, Galván A. Neural mechanisms of impulse control in sexually risky adolescents. Developmental Cognitive Neuroscience. 2013;6:23-29. https://doi.org/10.1016/j.dcn.2013.06.002

3. Ryu K, Lee M, Kim Y, Ban S, Choi M. How does advance provision of emergency contraceptives affect contraceptive use and sexual activity among adolescents? Systematic review and meta-analysis. Journal of Korean Academy of Nursing. 2018;48(3):255-265. https://doi.org/10.4040/jkan.2018.48.3.255

4. Subbarao NT, Akhilesh A. Knowledge and attitude about sexually transmitted infections other than HIV among college students. Indian Journal of Sexually Transmitted Diseases and AIDS. 2017; 38(1):10-14. https://doi.org/10.4103/0253-7184.196888

5. Mmbaga EJ, Leonard F, Leyna GH. Incidence and predictors of adolescent's early sexual debut after three decades of HIV interventions in Tanzania: A time to debut analysis. PLoS One. 2012; 7(7):1-9. https://doi.org/10.1371/journal.pone.0041700

6. Cheung KK, Montgomery D, Benjamins LJ. Prevalence of sexually transmitted infections among adolescents entering child pro- 
tective services. Journal of Pediatric and Adolescent Gynecology. 2015;28(5):324-326. https://doi.org/10.1016/j.jpag.2014.09.011

7. Dittus PJ, Michael SL, Becasen JS, Gloppen KM, McCarthy K, Guilamo-Ramos V. Parental monitoring and its associations with adolescent sexual risk behavior: A meta-analysis. Pediatrics. 2015; 136(6):e1587-e1599. https://doi.org/10.1542/peds.2015-0305

8. World Health Organization. Sexually transmitted infections [Internet]. Geneva: World Health Organization; 2014 [cited 2019 November 15]. Available from:

http://apps.who.int/iris/bitstream/handle/10665/112323/WH O_RHR_14.10_eng.pdf;jsessionid=B356033242680585AD906A568 D89A2E9?sequence=1

9. Lee IS. Historical changes and the present situation of sexually transmitted diseases. Journal of the Korean Medical Association. 2008;51(10):868-874.

https://doi.org/10.5124/jkma.2008.51.10.868

10. Jeong AS, Kim HS. Development and validation of benefits, barriers, and self-efficacy measurement tools for condom use among college students. Journal of the Korean Data Analysis Society. 2018;20(3):1519-1536.

https://doi.org/10.37727/jkdas.2018.20.3.1519

11. Park JJ, Seo YB, Jeong S, Lee J. Prevalence of and risk factors for sexually transmitted infections among Korean adolescents under probation. Journal of Korean Medical Science. 2017;32(11):1771-1778. https://doi.org/10.3346/jkms.2017.32.11.1771

12. South Korea Disease Control Headquarters. 2017 Annual report on HIV/AIDS [Internet]. Seoul: South Korea Disease Control Headquarters; 2017 [2019 November 30]. Available from:

http://www.mohw.go.kr/upload/viewer/skin/doc.html?fn=15 33777542028_20180809101902.pdf\&rs=/upload/viewer/result/ 202012/

13. AIDS Virus Education Research Trust (AVERT). Young people, HIV and AIDS [Internet]. UK: AVERT; 2018 [2019 November 30]. Available from:

https://www.avert.org/professionals/hiv-social-issues/key-affe cted-populations/young-people

14. Centers for Disease Control and Prevention. How you can prevent sexually transmitted disease [Internet]. Atlanta: Centers for Disease Control and Prevention; 2016 [cited 2019 November 15]. Available from:

https://www.cdc.gov/std/prevention/default.htm

15. Ramiro L, Reis M, Matos MG, Diniz JA. Trends in adolescent sexual behavior, impact of information, and attitudes about HIV/ AIDS in Portugal. Psychology, Health and Medicine. 2014;19(5): 614-624. https://doi.org/10.1080/13548506.2013.845299

16. Farrington EM, Bell DC, DiBacco AE. Reasons people give for using (or not using) condoms. AIDS and Behavior. 2016;20(12):2850-2862. https://doi.org/10.1007/s10461-016-1352-7
17. Widman L, Noar SM, Choukas-Bradley S, Francis DB. Adolescent sexual health communication and condom use: A meta-analysis. Health Psychology. 2014;33(10):1113-1124.

https://doi.org/10.1037/hea0000112

18. Lucea MB, Hindin MJ, Gultiano S, Kub J, Rose L. The context of condom use among young adults in the Philippines: Implications for HIV prevention. Health Care for Women International. 2013; 34(3-4):227-248. https://doi.org/10.1080/07399332.2012.721414

19. Cho GY, Kim YH. Factors affecting sexual autonomy among female university students. Journal of the Korea Academia-Industrial cooperation Society. 2014;15(11):6710-6718. https://doi.org/10.5762/KAIS.2014.15.11.6710

20. Lee J. Factors affecting contraceptive use among adolescent girls in South Korea. Child Health Nursing Research. 2017;23(3):259-267. https://doi.org/10.4094/chnr.2017.23.3.259

21. Whittemore R, Knafl K. The integrative review: Updated methodology. Journal of Advanced Nursing. 2005;52(5):546-553. https://doi.org/10.1111/j.1365-2648.2005.03621.x

22. Gough D. Weight of evidence: A framework for the appraisal of the quality and relevance of evidence. Research Papers in Education. 2007;22(2):213-228. https://doi.org/10.1080/02671520701296189

23. Kang HS. An explanatory model of condom use among Korean college students [dissertation]. Seoul: Yonsei University; 2001. p. 1-121.

24. Helweg-Larsen M, Collins BE. The UCLA multidimensional condom attitudes scale: Documenting the complex determinants of condom use in college students. Health Psychology. 1994;13(3): 224-237. https://doi.org/10.1037/0278-6133.13.3.224

25. Lee SY, Byun SJ, Kim JH, Kim HS, Park JS, Lim JM, et al. National survey of artificial abortion in South Korea. Policy Report. Sejong: Korea Institute for Health and Social Affairs; 2019. Report No.: 2018-66.

26. Norris AL, Rich C, Krieger N, Guthrie KM, Kaplan C, Carey KB, et al. Sexual risk behavior and substance use among young, diverse women seeking care at a reproductive health clinic. BMC Women's Health. 2019;19(1):15. https://doi.org/10.1186/s12905-019-0709-2

27. Osorio A, Lopez-del Burgo C, Ruiz-Canela M, Carlos S, Irala J. Safe-sex belief and sexual risk behaviours among adolescents from three developing countries: A cross-sectional study. BMJ Open. 2015;5(4):e007826.

https://doi.org/10.1136/bmjopen-2015-007826

28. Hwang SW, Chung CW. Contraception behavior and related factors in unmarried female and male. Korean Journal of Women Health Nursing. 2011;17(1):77-87.

29. Yeom GJ, Kim I. A study about research of needs for development of sex education program on university entrants. Korean Parent Child Health Journal. 2018;21(1):11-19. 